\title{
The Impact of Differences in Political and Economic Systems on the Internationalization of Companies- Results of Qualitative Research
}

\author{
Aleksandra Olejnik-Nizielska \\ University of Economics Katowice, Katowice, Poland
}

This paper provides insights and evidence related to the role of two of the psychic distance factors (differences in political and economic systems) in the process of Polish companies' internationalization. Psychic distance is a concept widely used in international business and international marketing literature to assess differences in culture, economic, and political systems as well as differences in mentality and geographic distance. The objective of the paper was to identify the impact of political and economic differences on main decisions of Polish managers connected with internationalization and engagement in international business activity. The direct research allowed answering two research questions: What are the perceptions of managers about Psychic Distance and its stimuli (differences, differences in economic and political systems) between Poland and markets of foreign expansion of Polish companies? What is the impact of psychic distance stimuli differences in economic and political systems on the process of Polish companies internationalization? The paper is based on the critical literature overview and on the field research conducted on the sample of 13 Polish companies with the technique of in depth interview. The depth interviews were conducted with export and marketing managers and directors of Polish companies. In the first theoretical part of the article, different approaches to conceptualization, operationalization, and measurement of psychic distance were compared. The critical literature overview led to the conclusion that there is a need for researchers to rethink the conceptualization, operationalization, and measurement of the phenomenon and factors of psychic distance. It is assumed that psychic distance should be considered at the individual level, the factors having impact on managerial perceptions of differences among countries depend on the environmental factors, companies characteristics, and managers' features. There is applied a methodology stating that psychic distance (and its stimuli) should not be measured only with the use of objective constructs and statistical data, but with the use of subjective data, such as the responses of decision makers. The results of depth interviews contain the essence of understanding in qualitative research, essentially, meaning knowledge based on experience, the confrontation of theoretical constructs with an empirical "world" and creation of the preliminary theory by the identification of constructs, when a priori assumption does not exist. The second empirical part of the article presents field research results on the importance of differences in political and economic systems in the process of companies internationalization. Empirical research reveals that differences in political and economic systems constitute important factor having

\footnotetext{
Aleksandra Olejnik-Nizielska, Ph.D., associate professor, International Management Department, University of Economics Katowice, Katowice, Poland.

Correspondence concerning this article should be addressed to Aleksandra Olejnik-Nizielska, International Management Department, University of Economics Katowice, Bogucicka str. 14, 40-226 Katowice, Poland.
} 
impact on companies' internationalization. They have the most significant impact on the number of countries subject to a company's foreign expansion, the choice of directions for a company's foreign expansion and the value of capital engagement on foreign markets. Such differences are also a crucial factor in making decisions on the withdrawal of business operations from international markets.

Keywords: psychic distance, political factors, economic factors, companies' internationalization, triangulation of methods, qualitative methods

\section{Introduction}

The process of globalization and economic integration favors the internationalization of companies. One phenomenon which has an impact on internationalization is psychic distance, a concept which is broadly discussed in the literature. Research has been conducted on the importance of this factor in the decision-making process relating to companies' export activities, the choice of forms and strategies of companies' foreign expansion, and decisions on the standardization and adaptation of marketing strategy implemented by companies operating on international markets.

The importance of different psychic distance stimuli (differences in culture, differences in political and economic systems, and differences in mentality and geographic distance) in the internationalization process of Polish companies is the subject of both qualitative and quantitative research conducted by the author. However, only the impact of differences in political and economic systems will be presented in the current article. For the purposes of the article and whole research project, economic differences were operationalized as follows: including the level of economic development-measured by GDP per capita, the level of infrastructure development, situation in the labour market in the region. In turn, political differences were operationalized as: the role of the government in the country, the level of democracy, and political stability.

Political and economic factors are treated here as the psychic distance stimuli (Dow \& Karunaratna, 2006).

The first theoretical part of the article consists of a comparison of differences in the conceptualization, operationalization, and measurement of psychic and cultural distance. The second empirical part of the article presents qualitative research results relating to managerial perceptions of the impact of political and economic factors on Polish companies' activity on international markets.

The conducted research enabled the author to answer the following research questions: What are the perceptions of managers about the differences in economic and political systems among Poland and the foreign expansion markets of Polish companies? What is the impact of differences in political and economic systems on the process of Polish companies internationalization (the directions and forms of internationalization, the pace and amount of countries subject to foreign expansion of Polish companies, and the value of sales and foreign capital engagement of Polish companies abroad)? What is the impact of differences in economic and political systems on managers' decisions connected with engagement on international markets (initiating business with foreign partners, leading business on international markets, and withdrawing business from international markets)?

To obtain the comprehensive results, joining the qualitative and quantitative methods is necessary.

\section{Theoretical Foundations}

Researchers and scholars have strived to comprehend and evaluate the nature of psychic distance and its 
impact on the process of internationalization of companies. During the past six decades, this has been cited as an important predictor variable for: the decision to export (Holzmutter \& Kasper, 1991); market selection decisions (Dow, 2001); entry mode choices (K. D. Brouthers \& L. E. Brouthers, 2001; Tihanyi, Griffith, \& Russel, 2005); the degree of adaptation in foreign markets (Sousa \& Bradley, 2005; Sousa \& Lages, 2011; Dow, 2001); international performance (Evans \& Mavondo, 2002; Evans, Mavondo, \& Bridson, 2008); and a variety of other international phenomena (Nordmann \& Tolstoy, 2014). There is evidence of measuring the effects of the interaction among cultural distance, perceived psychic distance, and psychic distance stimuli on the process of internationalization. A large sector of the International Business (IB) field, along with other fields (such as international marketing and international management), has dedicated themselves to research on the role of the aforementioned constructs in the internationalization process critically reviewed by Harzing (2004), Dow and Karunaratna (2009).

Due to the volume of the article, a limited number of remarks on the conceptualization and operationalization of the psychic distance construct will be presented herein.

The concept of psychic distance was originally introduced by Beckerman (1956) in 1956, as an afterthought to a study on the impact of relative economic distance on trade patterns. Psychic distance was introduced as a subjective influence moderating the role of objective economic distance (Beckerman, 1956). At the beginning, however, no extensive research was conducted in order to analyze the impact of psychic distance on the choice of foreign markets. Subsequently, in the 1970s, this concept was further developed by Johanson and Vahlne (1977), the authors of the sequential model, as mentioned above. These economists from Uppsala University define psychic distance as a set of factors preventing or disturbing the flow of information between the firm and the market (Johanson \& Vahlne, 1977; Johanson \& Wiedersheim-Paul, 1975). These difficulties may be directly related to communication with existing and potential customers. It has been stated that the internationalization process (as well as other international business transactions) is not only determined by objective economic realities, but also influenced by the availability of information and by the decision-maker's cognitive capabilities (Hakanson \& Ambos, 2010).

When describing the insights into the reasons for various degrees of businesses' market entry into, references are often made to managers' "psychic distance" to operating abroad (Albaum, Strandskov, \& Duerr, 2002). This reflects the managers' subjective impressions and emotions towards a foreign country and also has an ultimate impact on whether a company opens up and decides to commence operations abroad or chooses to limit its market connections (Albaum et al., 2002). Cultural distance, in turn, is defined as the differences between the culture of one's own country and the culture of a target country (e.g., an export destination). In this approach, the term of psychic distance refers to the perception, e.g., of customers' needs and expectations in a foreign country (Sousa \& Bradley, 2006; Sousa \& Bradley, 2008). The distance is culturally-determined but subjective. Cultural distance has a more objective character-it acknowledges the existing cultural differences (Ibid.).

Dow and Karunaratna (2006) and Dow and Larimo (2009) have distinguished the term "perceived psychic distance" from the psychic distance stimuli. The former referred to the managers' perception of factors (measured by psychic distance stimuli) which distort the flow of information between different markets. Although culture is considered to be one of the factors of psychic distance stimuli (Dow \& Larimo, 2009), this is usually operationalized in simple form by the values of Kogut and Singh (1988), and Avloniti and Filippaios (2014). 
Special consideration is given in this article to the differences in political and economic system among nominated countries (Dow \& Karunaratna, 2006). Commentators ranging from Carlson (1974) to Child, Hong, and Wong (2003), such differences as a potential psychic stimulus, but few researchers (Goerzen \& Beamish, 2003) have employed it in their empirical research. Differences in political systems can potentially impact managers on two levels. First of all, industries must necessarily involve a substantial amount of business-to-government and government-to-business communication. Differences in political systems will tend to increase the costs of uncertainty of such communications. Governments also play a key role in policing various business-to-business and business-to-consumer interactions, such as the enforcement of contracts and the monitoring of anti-competitive behavior. As a result, differences in political systems increase the risk that foreign firms might misjudge how a government is likely to reach in specific situations, and how other firms are likely to react in the light of any potential government intervention. Both of these phenomena have the potential to increase the costs and risks of doing business in a foreign country, thus influencing market selection decisions (Dow \& Karunaratna, 2006).

Attempts to operationalize psychic distance and empirically test its relevance remain relatively limited, although generally speaking, they are on the increase (Ghemawat, 2001; Brewer, 2007; Prime, Obadia, \& Vida, 2009). This applies to both the number of empirical studies on psychic distance and to the sophistication of the measurement instruments which have been developed (Shoham \& Albaum, 1995; Sousa \& Bradley, 2008; Sousa \& Lages, 2011).

In this article, special consideration is given to measuring the differences in political and economic systems. There are different examples of research on the impact of political (institutional) factor of international business activity of companies (Jonsson \& Lindbergh, 2010). Dow and Karunaratna (2006) proposed the following measurement scale of differences in political systems (differences in degree of democracy or political freedom) among countries, as represented by four variables. The first, variable is Henisz's (2000) polcon scale of comparison, which measures the degree of political constraint within a country. The second, measure of "democracy" and "autocracy" is the polity IV instrument (Gleditsch, 2003). The two final "democracy" variables come from Freedom House (2000). The selected indicators represent differences in "political rights" and "civil liberties" across nations. The second political dimension, which is less commonly measured, also exists. The right-centre-left scales of Beck, Clarke, Groff, Keefer, and Walsh (2001) measure "the policy preferences or ideological leanings of the decision-makers in each country". The mean difference of scores among countries is calculated based on the ideological leanings of the chief executive party (e.g., president) and the largest political party within the government.

There are different approaches to the measurement of differences in economic systems among countries. Vahlne and Wiedershein-Paul (1973) measured the differences in industrial development with the use of such indicators like: GDP per capita, consumption of energy and steel, a number of phones per 1,000 inhabitants as the indicators. Kobrin (1976) employed a broader range of 10 items including the percentage of employment in agriculture, consumption patterns (e.g., phones, radio, and newspapers), the degree of urbanization, and the GDP per capita. Dow and Karunaratna (2006) proposed the following measures: the difference in GDP per capita, the differences in consumption of energy, the vehicle ownership, the percentage of employment in agriculture, the percentage of GDP from manufacturing, the difference in degree of urbanization, and the differences in the development of the communication infrastructure (newspapers, radios, telephones, and TV sets per 1,000 population). 
According to the author of the article, none of the aforementioned classifications of psychic distance stimuli is sufficiently comprehensive, which has led to the preparation of the author's own system of classification. For the purpose of this study, the following classification of psychic distance stimuli is presented: cultural differences (including differences in values and norms, differences in languages, and differences in religion), economic differences (including the level of economic development-measured by GDP per capita, and the level of infrastructure development, situation in the labour market in the region), political differences (including the role of the government in the country, the level of democracy, and political stability), the differences in mentality (different way of thinking of managers, the managers' attitude to the reality, and the rules, with which the entity is heading during processing information from the market/environment), and geographic distance (distance in kilometres, transportation costs, and differences in time zones).

A number of authors have conceptualized and operationalized psychic distance in a variety of ways.

Current methods of measuring the psychic distance phenomenon are not without their critics. A major issue is that measurement development procedures do not take into account the perceptual nature of the phenomenon. Psychic distance is conceived as a perceptual and subjective phenomenon, but is typically operationalized as an objective, collective construct-an inconsistency that has been perpetuated over time (Hakanson \& Ambos, 2010). Perception is interpretative and highly subjective in terms of the individual's personal experiences and cultural value systems (Swift, 1999). As a consequence, the development of a measure of perceptual psychic distance should involve decision makers from the very beginning. If respondents are given a list of factors generated from the literature and asked to evaluate their degree of psychic distance stimuli, the subjective aspects of such perceived psychic distance are limited to the researchers' a priori conceptualization of psychic distance. Acknowledging the subjectivity of psychic distance stimuli perception is of crucial importance as decision makers themselves are confronted with the potential problems which result from psychic distance, and therefore should be able to identify the issue as the origin of such problems (Prime et al., 2009).

According to the author's view, qualitative methods could be appropriate when investing on the role of psychic distance in companies' internationalization. The examples of qualitative research on the perceived psychic distance are presented in the following articles: Child, Rodrigues, and Frynas (2009) and Prime et al. (2009).

\section{Research Methodology}

As previously mentioned, the research conducted by the author focused on the investigation of the impact of overall psychic distance and psychic distance factors, in the process of Polish companies' entry into international markets. To this end, a hypothesis was established that the psychic distance between Poland and the foreign markets onto which Polish companies are expanding is an important determinant of managerial decisions concerning internationalization. In order to fulfill the aforementioned research objectives, it was deemed necessary to combine various research methods (the so-called triangulation of methods), therefore the following research methods and techniques should be used: a critical review of literature on the subject; desk research; field research in the form of qualitative research carried out using in-depth interviews (on a sample of 13 companies); and quantitative research with the use of face-to-face interviews (on a sample of 200 companies). Special consideration should be taken into building instruments for field research. 
The article presents only the results of qualitative research on the impact of one of the psychic distance stimuli-differences in political systems—on the process of Polish companies' internationalization.

\section{Sampling}

Qualitative research in the form of depth interviews was undertaken in the period between July 2013 and April 2014. This research was undertaken within the territory of Poland; the research objects were Polish companies undergoing the process of internationalization; and the research subjects were managers' perceptions of the psychic distance between Poland and the foreign expansion markets of Polish companies.

Purposive sampling was selected for the research. The rules of sampling were chosen in accordance with methodology proposed by Miles and Huberman (2000), and research was conducted on a sample of 13 companies.

The sample was consisting of Polish companies. The list of companies, as the subjects of the research, was created on the basis of the general knowledge of the researcher and the following lists and rankings of Polish exporters: the rankings of the Ministry of Economy; "Sława Polski", "Orzeł Eksportu", and "Dobra firma"; the "Lista 500" Polityki ranking of the most significant Polish companies; the list by "Stowarzyszenie Eksporterów Polskich", and the "Liderzy Eksportu" ranking of Polish companies.

The criteria for choosing the cases were as follows: origin of capital (100\% Polish capital); experienced in activity on foreign markets (more than five years); value of sales on foreign markets during the last two years (more than $10.00 \%$ of total sales); and the geographic spread of foreign sales (companies should operate in more than 10 foreign markets). The criteria of $100 \%$ Polish capital ensured that the national culture of the companies as subjects of the research was Polish (thus facilitating a contrast between Poland and foreign countries). In the author's opinion, the interviewees should ideally have experience in activity on international markets in order to formulate opinions on different psychic distance stimuli. This was measured by the time of activity abroad, the share of foreign sales in total sales, and the geographic spread of foreign activity.

On the basis of telephone contact, those responsible for managing export functions in the company were chosen, omitted and direct relations were subsequently established. Interviews were conducted directly during visits to export companies. Additionally, some telephone interviews were also included. The maneuverability of research was $30.00 \%$. Cases were developed based on interview data combined with information freely available on company websites.

\section{Characteristics of the Companies}

The majority of the companies were large (69.23\%) and medium-sized (30.76\%) companies, representing the mining industry (companies $\mathrm{B}$ and $\mathrm{C}$ ); the chemical industry (companies $\mathrm{F}$ and $\mathrm{J}$ ); the cosmetics industry (companies E and I); the food industry (company D); the pharmaceutical industry (company L); the ICT industry (company M); the vehicle industry (company G); the furniture industry (company A); the automation industry (company $\mathrm{H}$ ); and the aluminum profiles industry (company $\mathrm{K}$ ). The majority of the respondents were export directors and export managers (46.15\% of the respondents); sales and marketing directors $(23.07 \%$ of the respondents); international markets and regional directors (15.38\% of the respondents); marketing and communication managers ( $7.69 \%$ of the respondents), and assistants to export directors (7.69\% of the respondents). The companies are experienced in activity on international markets. The main features of the companies under research are presented in Table 1. 
Table 1

Characteristics of Polish Companies

\begin{tabular}{|c|c|c|c|c|c|}
\hline Company symbol & A & $\mathrm{B}$ & $\mathrm{C}$ & $\mathrm{D}$ & $\mathrm{E}$ \\
\hline Year of establishment & 1973 & 1922 & 1951 & 1992 & 1989 \\
\hline Industry & furniture & mining & mining & FMCG & cosmetics \\
\hline Key changes in structure & $\begin{array}{l}1973 \text {-establishment by a } \\
\text { private entrepreneur (family } \\
\text { owned company) }\end{array}$ & $\begin{array}{l}\text { 1922-establishment of the } \\
\text { private company } \\
\text { 1951-transformation the } \\
\text { company into the state } \\
\text { treasury company } \\
\text { 2002-purchasing with the } \\
\text { status of bankruptcy by a } \\
\text { private investor }\end{array}$ & $\begin{array}{l}\text { 1951-establishment of the } \\
\text { state owned company } \\
1993 \text {-transformation from } \\
\text { a state-run company into a } \\
\text { state treasury company. }\end{array}$ & $\begin{array}{l}\text { 1992-establishment by a } \\
\text { private entrepreneur (family } \\
\text { owned company) }\end{array}$ & $\begin{array}{l}\text { 1989-establishment by a } \\
\text { private entrepreneur (family } \\
\text { owned company) }\end{array}$ \\
\hline \multicolumn{6}{|l|}{ Total sales } \\
\hline 2005 & $126,927,964$ & $240,000,000$ & $4,780,059.3$ & $166,000,000$ & \\
\hline 2010 & $116,775,038$ & $664,000,000$ & $2,947,758.6$ & $476,300,000$ & ni \\
\hline $\begin{array}{l}2012 \\
2013\end{array}$ & $140,423,837$ & $1,200,000,000$ & $3,472,672.3$ & $460,000,000$ & \\
\hline \multicolumn{6}{|l|}{ Foreign sales } \\
\hline 2005 & $33,111,000$ & $60,000,000$ & & & \\
\hline 2010 & $16,016,000$ & $95,000,000$ & $2,721,285.3$ & $\begin{array}{l}12,231,000 \\
19,976,000\end{array}$ & ni \\
\hline $\begin{array}{l}\text { Starting year of foreign } \\
\text { sales }\end{array}$ & 2001 & 2005 & 1951 & 2004 & 2000 \\
\hline $\begin{array}{l}\text { First foreign expansion } \\
\text { market }\end{array}$ & $\begin{array}{l}\text { Czech Republic, Russia, } \\
\text { Ukraine, Great Britain }\end{array}$ & Russia & Germany, Russia & Germany & Lithuania \\
\hline Market expansion (years) & 13 & & 63 & 10 & 14 \\
\hline First foreign subsidiary & - & & Austria & - & - \\
\hline Foreign manufacturing units & - & $\begin{array}{l}\text { Russia, Ukraine, } \\
\text { Kazakhstan }\end{array}$ & - & - & - \\
\hline Exit from foreign markets & - & 2007-Iran & - & - & - \\
\hline
\end{tabular}


Table 1 continued

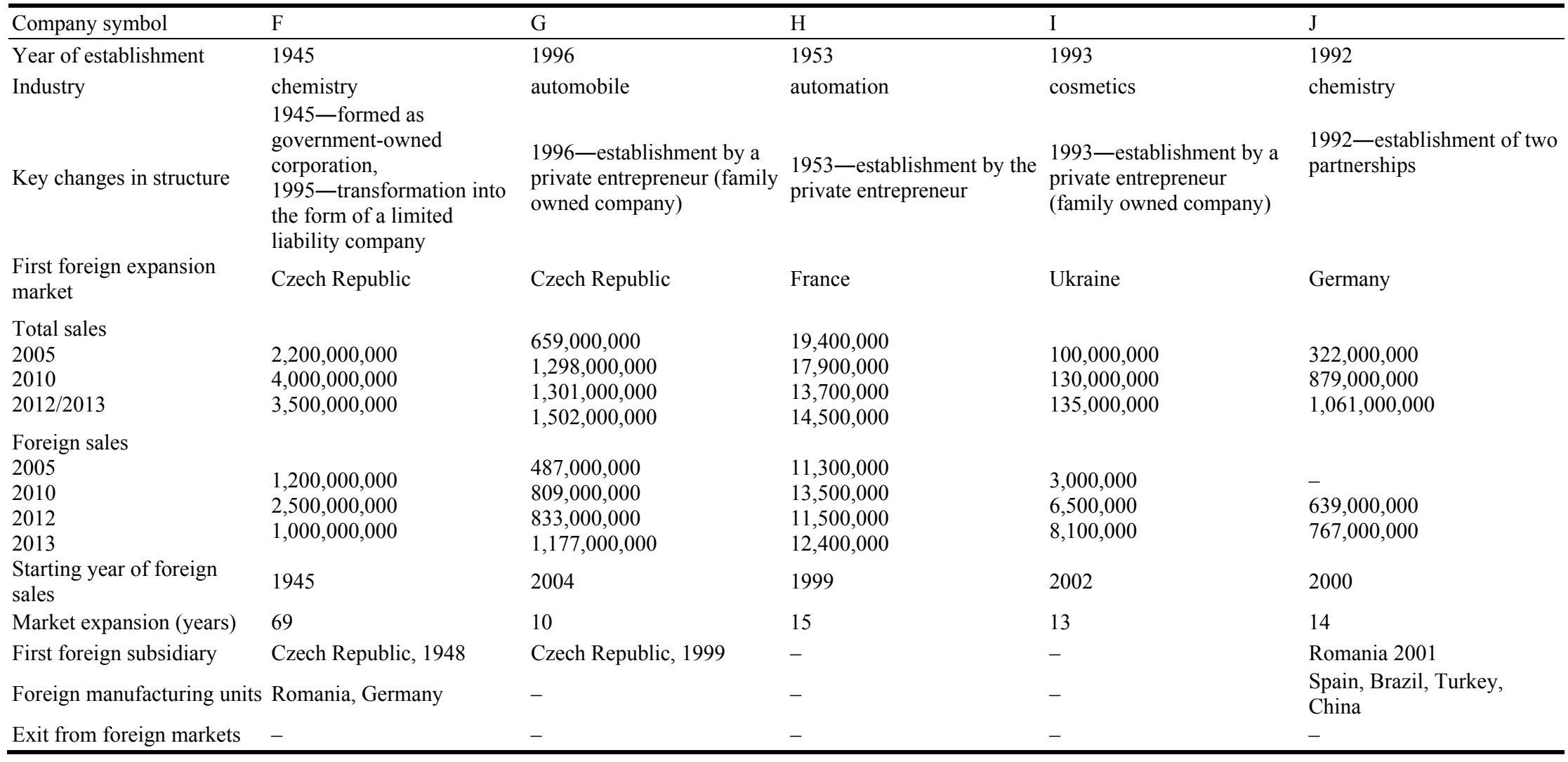


Table 1 continued

\begin{tabular}{|c|c|c|c|}
\hline Company symbol & $\mathrm{K}$ & $\mathrm{L}$ & M \\
\hline Year of establishment & 1953 & 1989 & 1991 \\
\hline Industry & aluminum profiles & pharmaceutical & ICT \\
\hline Key changes in structure & $\begin{array}{l}\text { 1953-establishing a State Owned company } \\
\text { 1993 - transformation into the form of a } \\
\text { limited liability company }\end{array}$ & 1989-company establishment & three offices in Poland \\
\hline $\begin{array}{l}\text { Total sales } \\
2005 \\
2010 \\
2012 \\
2013\end{array}$ & $\begin{array}{l}165,000,000 \\
196,000,000 \\
510,000,000\end{array}$ & $\begin{array}{l}151,586,000 \\
378,595,000 \\
406,303,000 \\
340,358,000\end{array}$ & $\begin{array}{l}80,000,000 \\
200,000,000 \\
263,000,000\end{array}$ \\
\hline $\begin{array}{l}\text { Foreign sales } \\
2005 \\
2010 \\
2012 \\
2013\end{array}$ & $\begin{array}{l}43,000,000 \\
64,000,000 \\
117,000,000\end{array}$ & $\begin{array}{l}26,993,000 \\
255,595,000 \\
309,803,000 \\
219,358,000\end{array}$ & $\begin{array}{l}78,000,000 \\
195,000,000 \\
245,000,000\end{array}$ \\
\hline Starting year of foreign sales & 2003 & 1999 & 1991 \\
\hline First foreign expansion market & Germany & Latvia & Sweden, Ukraine \\
\hline First foreign subsidiary & Hungary-2004 & Russia-2004 & - \\
\hline Foreign manufacturing units & Ukraine & Italy, Ukraine, India & Belarus, Ukraine, Sweden \\
\hline Exit from foreign markets & - & Russia-2010, Israel-2012 & $\begin{array}{l}\text { The Netherlands 2001, } \\
\text { Mexico } 2009\end{array}$ \\
\hline
\end{tabular}


Managers' opinions of the importance of differences in political systems in the process of internationalization of companies. The respondent representing company A noted the differences in political systems between Poland and the foreign expansion markets on which Polish companies are active. Such differences are related to democratic systems, the role of government in the country, political stability, and the quality of legal institutions. The most significant political differences are in Belarus and the Ukraine, likely resulting from the lack of democracy and political stability. Differences in political systems affect decisions on the choice of foreign expansion markets and the choice of the form which internationalization they will take. Because of the higher political risk in Belarus, Ukraine, and Russia, company A is reluctant to choose the most advanced form of internationalization. Political risk also reduces the number of foreign expansion markets, as the company fears entering foreign markets with an unstable political situation, of which one such example would be Belarus. According to the manager of company A, it would be necessary to introduce a democratic system in this country in order to make it viable to conduct business there. Belarus, however, continues to be perceived as under the control of an authoritarian regime.

Differences in political systems constitute a barrier to internationalization for the manager representing company B, who took into consideration social security in this country. For example, the unstable political circumstances in Egypt brought about his company's withdrawal from that market. This manager took into consideration the role of the democratic system within a country. According to him, "the more democracy in the country, the bigger the competition". Political conditions make it difficult to conduct business in Ukraine, where his company is unable to implement a clear business policy. The obligations placed upon entrepreneurs are ignored; there are no clear tax regulations, and corruption is rampant. This state of affairs causes uncertainty as to the feasibility of conducting business in that country and also the potential return on invested capital; thus, it is deemed too risky to apply more advanced forms of internationalization, which demand capital engagement in these countries.

The manager representing company $\mathrm{C}$ also noticed the clear differences in political systems. He admitted that political differences are not as important in countries belonging to the EU, because of the unified policy within this organization. Differences in political systems are taken into consideration by managers entering foreign countries not part of the European Union. A fine example is Egypt, where corruption, autocracy, and restrictions on the labor market may all be encountered. For him, the factors complicating cooperation with foreign partners are the lack of political stability on the foreign market and the quality of legal institutions.

The respondent representing company $\mathrm{D}$ also perceives the differences in political systems between countries-according to him, such differences can be easy to overcome. He made mention of tariff barriers, limiting the massive demand for business activity abroad. This manager has a negative opinion of the attractiveness of the Ukrainian market, believing that "the rules of law" should be implemented in that country and should be applicable to everybody. To improve investment conditions in this country, the interests of both employees and employers should be taken into consideration. Nowadays, industries originally developed by oligarchs are undergoing continued development, among them the energy, banking, and media sectors. Also viewed as important is the presence of a local partner with decent connections to the government, which constitutes the most important bridging factor reducing the perceived uncertainty of venturing into a new foreign market. As such, the process of identifying suitable partners, as well as establishing and managing relationships with them, is vital to the business' continued overseas expansion. 
The manager representing company $\mathrm{E}$ is of a similar opinion, as to him there is no point in choosing more advanced forms of internationalization (such as direct investment) on markets such as Ukraine and Belarus. This state of affairs is brought about by the unstable economic and political circumstances in these countries, as well as the prevalence of corruption. The respondent also made mention of the unstable legal system in these countries. Political conditions are important in post-communist countries such as China and Vietnam. The typical profile of a manager in these nations runs similar to that of a representative of the "powers that be". For the manager representing company $\mathrm{E}$, formal barriers to export activity can significantly impede activity on international markets.

According to the manager representing company $\mathrm{F}$, differences in political systems-and subsequently the regulatory environment-have a noticeable effect on decisions regarding internationalization. As an example, in the so-called "oligarchy" of Ukraine, the market is perceived as dangerous, as "the rules of the jungle" are the main regulations in force. Furthermore, in Belarus, local businessmen can have trouble gaining access to the single European currency. Under the circumstances, trade can even resemble a bartering process. Such countries are characterized by a lack of political stability.

The manager representing company $G$ perceived the impact of differences in political systems on decisions concerning internationalization. The German government strongly encourages the internationalization of domestic companies; to this end, there is an active lobbying policy, especially in the case of vehicles using alternative sources of energy. The level of market impenetrability is also a factor in the implementation of internationalization policies. Many decisions connected with the aforementioned industry are discussed at the government, self-government, and union levels, as in the United Arab Emirates.

According to the manager representing company $\mathrm{H}$, differences in political systems exist, and political factors cause restrictions in trade. Protectionist policies can create limits on international trade, tax barriers, dumping, and export subsidies. There are no clear rules for conducting business in Eastern countries. In order to decrease competition, the inflow of goods from abroad is reduced. An alternative example is China, where a pro-export policy can be observed. Due to government's subsidies, there is massive price competition on this market.

The manager of company I stated that his company undertakes activity on each international market without regard for political systems. However, political instability has an effect on quality and risk inherent in activity on international markets. As an example, the company has a highly competent partner on the Belarusian market, but the political and economic system in that country limits business opportunities. The devaluation of currency also brought about limitations on the value of sales-in fact, clients experienced falls in sales revenue of up to $30 \%$. The most basic risk of their activity on international markets is the failure of foreign partners to settle outstanding debt.

For the manager representing company $\mathrm{J}$, the most important factor hindering international trade changes to the regulatory environment, about which foreign partners are often not informed. The next problem is the highly individualized decisions made by officers (clerks), which are not based on legal regulations. As an example he cited Russia, where the authoritarian system is prevalent and decisions are generally made on an individual basis. Political stability and the associated sense of day-to-day security are the only guarantees when conducting business within a country. The autocratic system guarantees a company's operations on the foreign market. Low levels of democracy bring about corruption. Ukraine is perceived as a "fickle market", where nobody can predict events. Such circumstances have a direct impact on decisions on investment in that country. 
According to the manager representing company $\mathrm{K}$, political systems could cause uncertainty on foreign markets. Various institutions encourage business activity on international markets, in forms such as export subsidies. This manager finds it difficult to co-operate with Ukrainian managers, who differ from Poles in terms of mentality. Standards of both responsibility and ethics are lower. The respondent described Russian and Ukrainian managers as "people who need quarantine for a period of 20 years". In his estimation, Poland has taken enormous strides in recent years. Polish managers tend to adhere to international standards and establish long-lasting business relationships.

Political stimuli are also considered important in making decisions on internationalization by the manager representing company L. Such circumstances can apply when the market is regulated by the government. The political system may also influence the decisions of the courts concerning litigation. Another political factor is corruption, which is considered important on each level of business. In numerous business situations, managerial decisions are dependent on the decisions of clerks. According to the manager of company L, the rules of business are followed in each country in which his company operates.

The respondent from company $\mathrm{M}$ also noted the differences in political systems between Poland and the foreign expansion markets of the company he represents. He outlined the clear delineation between the so-called "Eastern" and "Western" parts of the world, noting the role of the government in business activity, which can hinder operations. Political differences do not have an effect on his company's activity on the German, Scandinavian, and American markets. According to the respondent, the most definitive elimination of differences in political systems was brought about by Poland's accession to the European Union. The quality of legal institutions, or lack thereof, is another important political factor, as this manager observed in Mexico which he labeled a "Latin mess". As a further contrast, the level of public safety in the Ukraine cannot be assured. The company decided to expand into the Russian market due to the interationalization of business. There is a perceived lack of business stability on Eastern markets such as Belarus and Ukraine.

Managers' opinions of the importance of differences in economic systems in the process of internationalization of companies. The respondent of company A stated that there are not many differences in economic systems between Poland and Central European countries (Czech Republic, Hungary). More significant differences are observed between Poland and more developed European countries, such as France and Germany, or Japan and the United States. The most significant differences are connected with the level of economic development, unemployment rate, inflation rate, and the wealth of the society. According to the manager of company A, differences in economic systems have huge impact on decisions connected with internationalization and they are still being treated as a barrier of internationalization. The fact that Poland is less developed than other European countries has impact on the country of origin of Polish products. Polish products are still being perceived as being of less quality and it is difficult to position them as luxury products in the most developed countries. The company A does not want to enter less developed foreign markets. The reason of it is the anxiety of the terms of payments by the business partners. The other economic criteria taking into consideration by the company A is the prosperity of the society. The company A did not enter the Slovak market (despite the geographic distance is close), because Slovak society is not perceived as rich. The company is focused on the regions inhabited by the well educated and rich social class, which ensures demand for the company's products. The differences in economic systems do not have impact on the choice of the internationalization form of company A, but in future the company plans the choice of more advanced form of internationalization in countries, where economic situation is stable, infrastructure is better developed, and the 
public safety is higher. The differences in economic systems have impact on the initiating relations with foreign partners. According to the manager of the company A, it is easier to establish relations with partners coming from countries of the same level of economic development.

The respondent representing company B also saw the differences in economic systems between Poland and foreign expansion markets of company he manages. For him the most important are tariff barriers, patents and intellectual property law, norms, and standards obligatory in each country (it results from the specific features of products offered by the company). The respondent of company B took into consideration the life cycle of the products on international markets. Polish products, which are not being sold in Poland find demand on international markets. The results of protectionist policy used by different countries are the embargo on companies' products, the difficulties in financial transfers (the example was the blockade the SWIFT transactions in Iran). Because of the fact that the clients of the company are public enterprises, the impact on transaction of the company has also fiscal deficit. In countries such as Romania, there is a huge impact on inflation on the regulation of the country on the activity of coal mines. It also has impact on financing the investments in these companies. The company B's representative mentioned about the importance of stability of financial institutions for establishing economic transactions. Because of the huge values of transactions, it is important to use different financial instruments, such as: bank guarantees, letter of credit, and leasing. It is important to verify the financial situation of the host country and of the company-the party of the transaction. The respondent representing company B gave the example of Africa. He noticed that the banking system in Africa is less developed than in Poland. The transaction was not performed there, because it was not possible to find proper bank. Another issue is difficult situation in the competitive market, which is the result of subsidizing export. It is connected with the products coming from China. For the respondent representing company B, what important is also situation on the labor market. The unfovarable is the fact that there is a cheap labor force in Chinese market. It means that it will be difficult to substitute labour force with the machines.

The differences in economic systems are also important for the respondent representing company C. He took into consideration the situation in the industry, which he represents (energy). According to him, globalization caused that differences in economic systems do not have impact on decisions connected with internationalization. His clients are huge transnational corporations, he makes B2B transactions, and the products of the company come to individual clients. Because of the fact of the huge values of transactions when he decides to enter foreign markets, he just took into consideration the financial situation of the expansion country and the company-business partner. The manager of company $\mathrm{C}$ took into consideration the way of protection of business transaction. As its foreign expansion field, he chooses less rich countries, under the condition that the company has good reputation and good financial situation. Nowadays, the company concentrates mainly on European countries, which are for the respondents the most "natural markets", and the clients are the most reliable.

Also the manager representing company D saw the necessity of taking into consideration differences in economic systems between countries. The importance for him is the wealth of the clients in the host country. The same as the respondent representing company A, he gave the example of Slovakia. This is the requirements of low prices, to be competitive in the foreign markets. Because of the delays of payments, it is difficult to cooperate with the Greek managers. The manager representing company D does not see the tariff barriers. Because of the fact that the company is realizing its transaction only on the EU markets, there are the same 
regulations connected with international trade. The respondent representing company $\mathrm{D}$ noticed that because of the much diversified assortment of products, the company is adjusting its products to consumer's preferences on each international market. The company is adjusting to local markets each marketing mix instruments. For the manager representing company $\mathrm{D}$, what very important is the development of economic, social, and transportation infrastructure on its foreign expansion markets.

The same differences in economic systems are noticed by the manager representing company E. For him, what the most important are factors making difficulties in payments. It is e.g., the accession to the foreign currencies. The example is Belarus, where the partner could not make the bank transfer because the financial situation in the country is not stable, which makes changes in exchange rates. The difficulties in business activity are tax barriers and the lack of possibility of verification of business partners. The next issues are differences in income levels between Poland and foreign expansion markets of Polish companies.

In case of differences in economic systems, the manager of company F showed tax barriers connected with trade from beyond EU countries and restriction connected with the lack of competition. The respondent gave the example of China, from which country the company had to withdraw itself, because the antidumping tariffs were imposed. In contacts with Eastern countries, so-called registration of product is important. It causes the increasing of costs of launching the products on the market.

For the respondent representing company G, what important is the tender procedure in different countries. According to this, what important is preparing to foreign contacts. The respondent took into consideration the fact that the offer is being driven to countries, which prognosticate well, there are different ways of reaching clients in these countries. The next issues are subsidies. There is a question, who will be promoted: the country or the company from the country, for example, in France, what advantaged are French products. They have superiority in the access to the market. Preparing the order, the contractor reserves the components be produced in France. They have the primary access to the market. The next issue is financing the public transport or the exchange of transport means (for example, it was necessary to withdraw the diesel vehicles from some markets because of the environment protection). The companies chose alternative sources of propulsion. According to the respondent representing company $\mathrm{G}$, the differences in economic systems have impact on decisions connected with internationalization.

For the manager representing company $\mathrm{H}$, the important economic factor having impact on decisions connected with internationalization are securities of payment. The clients from developing countries are characterized with the aversion to risk. What important for them are instruments like: bill of sale, letter of credit, and prepayment. what important is also logistic, calculating the offer, and the development of business. There is no place for cooperation with country institutions. The managers of the company try to verify business partners to trust them. Taking decisions about expansion on the foreign market the manager makes two-way evaluation: the country-its stability and the partner-his experience, history, and references.

The manager representing company I was asked to identify the differences in economic systems. The clearest procedures of conducting business are in the European Union market. The respondent noticed the necessity of products registration, who should take the time of 1.5 year. It is connected with Arab countries. On the contrary, in North Korea there is a necessity of preparing very detailed documentation describing products. There is also embargo in Iran. In Algeria, the transaction was possible with the use of letter of credit. Tariffs and taxes increase the prices of products in countries like Russia and Brazil. The respondent gave the example of Brazil as strong and dynamically developing market. The purchasing potential of its inhabitants is huge. This 
country is very closed and hermetic to foreign countries. The monuments prefer national products, $96 \%$ of cosmetic market are Brazilian products.

The respondent representing company $\mathbf{J}$ showed the differences in economic systems between Poland and foreign expansion markets of Polish companies. The manager noticed the different structure of distribution in Poland and in the Kazakhstan. Poland is characterized by small distances among cities, but in Kazakhstan the distances are significant. It is the challenge for the logistic department. The respondent noticed the differences among foreign markets, in which the company operates. Ukraine is a very corrupted market, it is unpredictable. The barrier is a bit procedure in this country. Kazakhstan is a very dynamic market, it develops very quickly. Local entrepreneurship and local production are developing here. The respondent of company $\mathrm{J}$ took into consideration tariff barriers in export to Russia, Belarus, and Kazakhstan. These barriers cause the increase of prices of products being sold on these markets. The trade is being impeded by the lack of unified rules of documentation. The next criterion of conducting business in foreign countries is social and transportation infrastructure. The quality of life increases in these countries. Kazakhstan is a leader in Central Asia and the intermediary in trade with China. The dynamic development of country makes the good conditions for investment. According to the respondent of the company $\mathrm{J}$, differences in economic systems have impact on decision connected with internationalization. The manger of company $\mathrm{J}$ does not invest in Western European countries; the international activity of this company is focused on Russia, Kazakhstan, and Romania.

According to the manager representing company $\mathrm{K}$, there is a significant economic distance among Poland, Switzerland, and Germany. The differences in economic systems have impact on decisions connected with internationalization. For him it is better to contact with partners from developed countries, representing so called "Old Europe". The more favorable conditions of conducting business are in countries like Bulgaria, Romania, and Hungary. These countries are being perceived by manager representing company L as less developed than Poland. Both infrastructure and economic position of these countries are worse than in case of Poland. There are also not good conditions for investment. According to the manager of company L, the economic situation of the country has impact on business behavior of managers. The stable situation in foreign country encourages managers to enter into special foreign markets. What also very important is the analysis of economic environment of a country. The respondent mentioned about the differences in economic systems. One of the spheres is financial flows and making transactions in different currencies. According to the respondent, "the less currency in a country, the better to make business there". The region, where the unhampered activity is inhibited is the East of Europe. The biggest differences are connected with Belarus (where is the lack of private companies) and Ukraine (where the structure of the industry is different, the authority is oligarchic and where is corruption).

Economic environment is also important by making decisions by the manager representing company L. During transactions with local partners, what important are exchange rates and the engagement in business activity by local partners. Their image and financial position could be lower. What also important is the market position the company would like to achieve. The reason of withdrawal from local market could be the local partners' behavior and the lack of support on foreign markets.

The manager representing company $\mathrm{M}$ stated that more favorable conditions of conducting business are in EURO zone. Important factors taken into consideration by businessmen while making decisions about entering foreign markets are banking system and the possibility of giving crediting clients. While engaging in international activity by foreign direct investment, what important is also situation on the labor market and 
possessing staff for working in international companies of the company. According to the manager of company $\mathrm{M}$, the differences in economic systems have impact on decisions connected with activity on international markets. They caused the withdrawal from Mexican market. Also the expansion on Burma market was difficult. It is caused by the law level of scholarship there. The level of knowledge and competencies of engineers implementing IT systems is low there. The special education programs were created for them (Table 2).

Managers' opinions of the significance of differences in economic and political systems in the process of internationalization of companies. The managers were also asked to evaluate, on a scale of 1 to 5 , the significance ( 1 being the least important and 5 the most important) of the differences in political and economic systems in the process of internationalization and on the engagement into international markets. In order to identify the impact of the level of internationalization on the perceptions of managers of the role of political differences in the internationalization process, the samples were divided into four subsamples: I, II, III, and IV (Table 3).

Subsample I consists of less internationalized companies (in terms of value of foreign sales) and is comprised of companies A, B, D, E, I, and K. The value of foreign sales in these companies is up to $25.00 \%$ of total sales.

Subsample II consists of highly internationalized companies (in terms of value of foreign sales) and is comprised of companies C, F, G, H, J, L, and M. The value of foreign sales of these companies exceeds $25.00 \%$ of total sales.

Subsample III consists of less internationalized companies (in terms of the number of continents on which the company operates). Companies operating on up to three continents were assigned to this subsample, namely, companies D, E, F, G, H, and K.

Subsample IV consists of highly internationalized companies (in terms of the number of continents on which the company operates). Companies operating on more than three continents were assigned to this subsample, namely, companies A, B, C, I, J, L, and M.

The differences in political systems have the most significant impact on the number of countries subject to the foreign expansion of a company (the average of respondents' answers is 3.85). They may also affect the choice of directions for the companies' foreign expansion and the value of capital engagement on foreign markets (the average of respondents' answers is 3.77).

Managerial perception of the impact of the differences in political systems on the decisions relating to internationalization differs depending on the level of their company's internationalization.

Managers of companies in which the value of foreign sales does not exceed $25.00 \%$ of the total value of sales perceive the impact of differences in political systems to be more significant than that of managers of companies in which the value of foreign sales is above this $25.00 \%$ threshold. The former group perceives the most significant impact of differences in political systems to be manifested on the value of exports (the average of respondents' answers is 4.67), the choice of directions for the company's foreign expansion, and the number of countries subject to the foreign expansion of the company (the average of respondents' answers is 4.50). Companies in which the value of foreign sales exceeds $25.00 \%$ of total sales perceive that differences in political systems have the most significant impact on the choice of a company's market entry strategy (the average of respondents' answers is 3.86). 
Table 2

Managers' Opinions of the Importance of Differences in Political Systems in the Process of Internationalization of Companies

\begin{tabular}{|c|c|c|}
\hline Company & Differences in political systems & Differences in economic systems \\
\hline A & $\begin{array}{l}\text { - democratic system in the country, } \\
\text { - the role of the government in the country, } \\
\text { - the quality of legal institutions }\end{array}$ & $\begin{array}{l}\text { - the level of economic development, } \\
\text { - unemployment rate, } \\
\text { - } \text { inflation rate, } \\
\text { - } \text { the wealth of the society, } \\
\text { - } \text { punctual payments of partners, } \\
\text { - treated as a barrier of internationalization }\end{array}$ \\
\hline B & $\begin{array}{l}\text { - the level of safety in the society, } \\
\text { - the democratic system in the country }\end{array}$ & $\begin{array}{l}\text { - tax barriers, } \\
\text { - patents, } \\
\text { - intellectual property law, } \\
\text { - norms and standards obligatory and different countries, } \\
\text { - product life cycle on international markets, } \\
\text { - stability of financial institutions, } \\
\text { - situation on the labour market, } \\
\text { - fiscal deficit, } \\
\text { - financial instruments: bank guarantees, letter of credit, and leasing, } \\
\text { - the level of development of banking systems, } \\
\text { - the costs of labour force }\end{array}$ \\
\hline $\mathrm{C}$ & - corruption, bureaucracy & $\begin{array}{l}\text { - the impact of globalization on reducing economic differences between countries, } \\
\text { - financial situation of the country, } \\
\text { - financial situation of business partners, } \\
\text { - the way of protection of business transaction }\end{array}$ \\
\hline $\mathrm{D}$ & $\begin{array}{l}\text { - } \quad \text { tax regulations, } \\
\text { - } \text { stability of legal institutions, } \\
\text { - adherence to regulations }\end{array}$ & $\begin{array}{l}\text { - the level of clients' wealth in the host country, } \\
\text { - the preferences of clients in the host country, } \\
\text { - adjusting to local markets marketing mix instruments, } \\
\text { - the level of development of economic, social, and transportation infrastructure }\end{array}$ \\
\hline $\mathrm{E}$ & $\begin{array}{l}\text { - lack of stability within the legal system (Ukraine, Belarus), } \\
\text { - corruption, } \\
\text { - } \text { folitical conditions in post-communist countries: China, Vietnam, } \\
\end{array}$ & $\begin{array}{l}\text { - the factors making the payments difficult, } \\
\text { - accession to foreign currencies, } \\
\text { differences in income levels between Poland and foreign expansion markets of } \\
\text { Polish companies }\end{array}$ \\
\hline $\mathrm{F}$ & $\begin{array}{l}\text { - differences in legal systems in different countries, } \\
\text { - oligarchical policy on the Ukrainian market, } \\
\text { - lack of regulation and political stability in Ukraine }\end{array}$ & $\begin{array}{l}\text { - tax barriers with trade with countries beyond EU countries, } \\
\text { - restrictions connected with the lack competition, } \\
\text { - } \text { registration of products, } \\
\text { antidumping tariffs }\end{array}$ \\
\hline G & $\begin{array}{l}\text { - the support of the German government for the internationalization } \\
\text { process, } \\
\text { - lobbying policy of the German government, } \\
\text { the level of market impenetrability }\end{array}$ & $\begin{array}{l}\text { - tender procedure, } \\
\text { - } \text { the promotion of countries and of the companies, } \\
\text { - financing of public transport, } \\
\text { - devaluation of currency }\end{array}$ \\
\hline
\end{tabular}


Table 2 continued

\begin{tabular}{|c|c|c|}
\hline Company & Differences in political systems & Differences in economic systems \\
\hline $\mathrm{H}$ & $\begin{array}{l}\text { - restrictions in trade due to political factors, } \\
\text { protectionist policy: limits, tax barriers, dumping and export subsidies }\end{array}$ & $\begin{array}{l}\text { - securities of payment (bill of sale, letter of credit, prepayment), } \\
\text { - tendency to risk, } \\
\text { - logistic procedure, } \\
\text { the process of verifying business partners from the other countries (the stability of } \\
\text { the country and the experience of partner) }\end{array}$ \\
\hline I & $\begin{array}{l}\text { - the impact of political factors on the quality and risk of activity on } \\
\text { international markets, } \\
\text { - the limitation of business activity on the Belarusian market } \\
\text { (because of lack of stability of political systems), } \\
\text { - the devaluation of local currency }\end{array}$ & $\begin{array}{l}\text { - the necessity of products registration, } \\
\text { - detailed documentation describing products, } \\
\text { - the level of the development of the market, } \\
\text { - the purchasing potential of the inhabitants of the country, } \\
\text { - the impact of financial instruments like: embargo, tarrifs, and taxes, } \\
\text { - Brasil as a closed and hermetic country, } \\
\text { - lack of payment from local partners }\end{array}$ \\
\hline $\mathrm{J}$ & $\begin{array}{l}\text { - lack of stability of legal systems, } \\
\text { - individual decisions of clerks not based on legal regulations, } \\
\text { - the authoritarian system of management (Russia), } \\
\text { - } \text { corruption, } \\
\text { - Ukraine perceived as a fickle market }\end{array}$ & $\begin{array}{l}\text { - the different structure of distribution in different countries (e.g. the distances } \\
\text { between the cities in one country) } \\
\text { - tariff barriers to export to Russia, Belarus and Kazakhstan, } \\
\text { - the level development of a country, } \\
\text { - corruption in countries like Ukraine, } \\
\text { - } \text { social transportation infrastructure, } \\
\end{array}$ \\
\hline $\mathrm{K}$ & - institutions encouraging business activity on international markets & $\begin{array}{l}\text { - the size of economic distance between Poland and Western and Eastern countries, } \\
\text { - conditions for investment }\end{array}$ \\
\hline $\mathrm{L}$ & $\begin{array}{l}\text { - the impact of legal systems on courts, } \\
\text { - corruption important on each level of business, } \\
\text { - the rules of law important in each country in which the company } \\
\text { operates }\end{array}$ & $\begin{array}{l}\text { - analysis of economic environment of the company, } \\
\text { - the differences in economic systems, } \\
\text { - conditions of investment in Eastern and Western countries, } \\
\text { - the currency rate in a country }\end{array}$ \\
\hline M & $\begin{array}{l}\text { - delineation between East and West, } \\
\text { - the role of the government in business activity, } \\
\text { - Ge impact of political differences on company's activities on the } \\
\text { - Scandinavian and American market, } \\
\text { - the quality of legal institutions, } \\
\text { - lack of assurance of public safety in countries like Ukraine, } \\
\text { lack of political stability in Ukraine and Belarus }\end{array}$ & $\begin{array}{l}\text { - the differences in conducting business in EU and countries outside EU, } \\
\text { - situation on the labor market, } \\
\text { the level of knowledge and competencies of IT engineers and specialists }\end{array}$ \\
\hline
\end{tabular}

Source: own elaboration. 
Table 3

The Significance of Differences in Political Systems in the Process of Companies' Internationalization (the Average of Respondents Answers)

\begin{tabular}{|c|c|c|c|c|c|c|c|c|c|c|}
\hline \multirow[b]{2}{*}{ Specification } & \multicolumn{5}{|c|}{ Differences in political systems } & \multicolumn{5}{|c|}{ Differences in economic systems } \\
\hline & $\begin{array}{l}\text { Total } \\
\text { sample }\end{array}$ & I & II & III & IV & $\begin{array}{l}\text { Total } \\
\text { sample }\end{array}$ & I & II & III & IV \\
\hline $\begin{array}{l}\text { The choice of directions of } \\
\text { foreign expansion of the company }\end{array}$ & 3.77 & 4.50 & 3.14 & 3.83 & 3.71 & 3.77 & 4.50 & 3.14 & 3.86 & 3.71 \\
\hline $\begin{array}{l}\text { The choice of market entry } \\
\text { strategy of a company }\end{array}$ & 3.66 & 3.33 & 3.86 & 3.50 & 3.71 & 3.62 & 3.33 & 3.86 & 3.50 & 3.71 \\
\hline $\begin{array}{l}\text { The amount of countries subject } \\
\text { to foreign expansion of the } \\
\text { company }\end{array}$ & 3.85 & 4.50 & 3.29 & 3.67 & 4.00 & 3.69 & 4.67 & 2.86 & 3.67 & 3.71 \\
\hline $\begin{array}{l}\text { The pace of internationalization of } \\
\text { the company }\end{array}$ & 3.08 & 4.17 & 2.14 & 2.83 & 3.29 & 3.38 & 4.17 & 2.71 & 3.33 & 3.43 \\
\hline $\begin{array}{l}\text { The value of sales of the company } \\
\text { on the foreign markets }\end{array}$ & 3.54 & 4.67 & 2.57 & 3.50 & 3.57 & 3.77 & 4.67 & 3.00 & 3.50 & 4.00 \\
\hline $\begin{array}{l}\text { The value of capital engagement } \\
\text { on the foreign markets }\end{array}$ & 3.77 & 4.33 & 3.29 & 3.33 & 4.14 & 4.08 & 4.33 & 3.86 & 3.67 & 4.43 \\
\hline
\end{tabular}

The perception of the impact of differences in political systems also depends on the amount of continents in which the company operates. Managers of companies operating in three or fewer continents perceive that differences in political systems have the most significant impact on the directions of foreign expansion (the average of respondents' answers is 3.83). Managers of companies operating in more than three continents perceive that differences in political systems have the most significant impact on the value of capital engagement on the foreign markets (the average of respondents' answers is 4.14), as well as on the number of countries subject to the foreign expansion of a company (the average of respondents' answers is 4.00).

According to the managers, the differences in economic systems have the most significant impact on the value of capital engagement abroad (the average of respondents answers is 4.08), the value of sales of the company on the foreign markets and the choice of directions of foreign expansion of the company (the average of respondents answers is 3.77), the amount of countries subject to foreign expansion (the average of respondents answers is 3.69), the choice of market entry strategy (the average of respondents answers is 3.62), and the pace of internationalization of the company (the average of respondents answers is 3.38).

Managers' perceptions of the impact of differences in economic systems on the process of companies internationalization depend on the value of export of these companies and on the number of continents the company operates.

Managers of companies in which the value of foreign sales does not exceed $25.00 \%$ of the total value of sales perceive the impact of differences in economic systems to be more significant than that of managers of companies in which the value of foreign sales is above this $25.00 \%$ threshold. The former group perceives the most significant impact of differences in economic systems on the value of sales on international markets and on the amount of countries subject to foreign expansion (the average of respondents answers is 4.67), on the choice of directions of foreign expansion of the company (the average of respondents answers is 4.50 ), and on the value of capital engagement abroad (the average of respondents answers is 4.33).

The perception of the impact of differences in economic systems also depends on the amount of continents in which the company operates. Managers of companies operating in three or fewer continents perceive that 
differences in economic systems have the most significant impact on the choice of market entry strategy (the average of respondents' answers is 3.83), and the amount of countries subject to foreign expansion and the value of capital engagement abroad (the average of respondents' answers is 3.67). The managers operating in more than three continents perceive the most significant impact of differences in economic systems on the value of capital engagement abroad (the average of respondents answers is 4.43), the value of foreign sales of the company (the average of respondents answers is 4.00), the choice of directions of foreign expansion of the company, and the choice of market entry strategy and the amount of countries subject to foreign expansion (the average of respondents answers is 3.71) (Table 3).

The managers perceived the differences in political systems to have the most significant impact on the withdrawal of business activity from a certain market (the average of respondents' answers is 4.54), such impact was perceived by all managers, without regard to the level of companies internationalization. However, the most significant impact of political differences is perceived by managers of less internationalized companies in terms of the value of export (the average of respondents answers is 4.83) and by managers of highly internationalized companies in terms of number of the continents the company operates (the average of respondents answers is 4.57 ).

The respondents declared that the differences in economic systems have the most significant impact on the withdrawal of business activity from a certain market (the average of respondents answers is 4.38) and initiating business activity with a foreign partner (the average of respondents answers is 3.31). The differences in economic systems are less important factors in performing business activity from international markets (the average of respondents answers is 2.31). The level of companies engagement abroad does not have impact on managerial perceptions of the importance of differences in economic systems on decision connected with internationalization. No matter what is the level of companies engagement abroad (measured by the value of foreign sales and the amount of continents the company operates), differences in economic systems have the most significant impact on withdrawal of a business activity from international market (Table 4).

Table 4

The Significance of Differences in Political Systems in International Business Activity (the Average of Respondents’ Answers)

\begin{tabular}{|c|c|c|c|c|c|c|c|c|c|c|}
\hline \multirow[b]{2}{*}{ Specification } & \multicolumn{5}{|c|}{ Differences in political systems } & \multicolumn{5}{|c|}{ Differences in economic systems } \\
\hline & $\begin{array}{l}\text { Total } \\
\text { sample }\end{array}$ & I & II & III & IV & $\begin{array}{l}\text { Total } \\
\text { sample }\end{array}$ & I & II & III & IV \\
\hline $\begin{array}{l}\text { Initiating business activity } \\
\text { with foreign partner }\end{array}$ & 3.08 & 3.33 & 2.86 & 3.17 & 3.00 & 3.31 & 3.50 & 3.67 & 3.17 & 3.43 \\
\hline $\begin{array}{l}\text { Performing business activity } \\
\text { with foreign partner }\end{array}$ & 1.92 & 1.83 & 1.92 & 1.83 & 2.00 & 2.31 & 2.50 & 2.50 & 1.67 & 2.86 \\
\hline $\begin{array}{l}\text { Withdrawal of a business } \\
\text { activity from a certain market }\end{array}$ & 4.54 & 4.83 & 4.29 & 4.50 & 4.57 & 4.38 & 4.67 & 4.83 & 4.33 & 4.43 \\
\hline
\end{tabular}

\section{Conclusions}

The literature overview indicates that there are different approaches to defining and measurement of psychic distance and there is a need for researchers to rethink the conceptualization, operationalization, and measurement of this phenomenon. It is assumed that psychic distance should be considered at the individual 
level, the factors having impact on managerial perceptions of differences among countries depend on the environmental factors, companies characteristics, and managers' features.

The main advantage of the article is the presentation of a new approach to measuring psychic distance and especially one of its factors (political and economic factors). The aim of the applied methodology is the confrontation of theoretical constructs with an empirical "world" and creation of the preliminary theory by the identification of constructs, when a priori assumption does not exist. The chosen methodology allowed the measurement of the subjective opinions of managers regarding the importance of differences in political and economic systems-in practice, between Poland and the foreign expansion markets in which Polish companies operate.

Psychic distance was not measured with the use of objective constructs and statistical data, but with the use of subjective data, such as the responses of decision makers in the form of managers of Polish companies. The main source of information in the research was the answers of the respondents received while conducting depth interviews. They were discussing their perceptions of the differences in economic systems in international engagement of Polish companies.

The results of depth interviews contain the essence of understanding in qualitative research, essentially meaning knowledge based on experience, which in turn is related to the majority of questions asked by the interviewer. The interviewees' responses were treated as a mixture of opinions, feelings (emotions), descriptions, and interpretations. As the researcher was not able to accompany the respondents in the field and thus observe their activity first-hand, it was necessary to obtain knowledge of the features of this activity ex-post. To make the data collection process more objective, the researcher used the techniques of replication (conducting research on a sample of 13 companies) and triangulation of methods. Thus, the decision to continue the research with the use of quantitative methods was made.

Psychic distance needs to be viewed in terms of its changing context. The results indicate that political and economic differences are still relevant in the decision-making process as it relates to internationalization and the international activity of companies. These factors are taken into consideration in the decision-making process as they relate to developing business activity abroad, however they are not treated as a barrier to internationalization. Managers agreed that they are able to overcome such barriers to undertake business activity in cooperation with foreign partners.

The most significant political factors which have an effect on internationalization are as follows: the existence of a democratic system; the varying role played by government in different countries; lack of political stability; corruption; stability of legal institutions; differences between legal systems in different countries; the level of adherence to regulations; the government policy promoting foreign operations of companies; restrictions of foreign trade; protectionist policy; and the impact of policy on the decisions of courts of law.

The managers were also asked to evaluate the significance of the differences in political systems between Poland and the foreign expansion markets in Polish companies operating in different decisions concerning internationalization. Differences in political systems have the most significant impact on the number of countries into which a company expands, the choice of directions for a company's foreign expansion, and the value of capital engagement in foreign markets. Managers also evaluated the significance of differences in political systems in different aspects of international business activity. Without regard to the level of internationalization of companies, all managers stated that differences in political systems have the most significant impact on the withdrawal of Polish companies from certain markets. 
According to the managers, differences in economic systems also have significant impact on decisions connected with internationalization.

The differences perceived by managers are the following: the level of economic development of a country and business partner; foreign trade policy of the home and host country; fiscal policy of a home and host country; situation on the labour market; the level of development of the banking system accessing to financing instruments enabling international transactions; the consumer preferences in the host country; the level of development of economic, social, and transportation infrastructure; tax barriers; conditions of investment in Eastern and Western countries; the currency rate; tender procedure; tendency to risk of business partners; the purchasing potential and quality of life of business partners; and the country belonging to EU.

Respondents stated that the differences in economic systems have the most significant impact on the value of capital engagement abroad, the value of sales of the company on the foreign markets, and the choice of directions of foreign expansion of the company. Managers' perceptions of the impact of differences in economic systems in the process of companies internationalization depend on the value of export of these companies and on the number of continents the company operates.

It can be generalized that the managers of less internationalized companies (taking into consideration the value of export) perceive more significant impact of the psychic distance on companies internationalization. Different situation can be observed in case of highly internationalized companies, taking into consideration the number of continents the company operates. Managers of these companies perceive more significant impact on decisions connected with internationalization.

No matter what is the level of companies engagement abroad (measured by the value of foreign sales and the amount of continents the company operates), differences in economic systems have the most significant impact on withdrawal of a business activity from international market.

The first, exploratory stage of research enabled to formulate conclusions on the base of the unhampered managers' responses. The herded material allowed identifying the examples of differences in economic and political systems perceived as psychic distance stimuli. Conducted depth interviews allowed also identifying the manager's perceptions about the significance of economic and political factors in decisions about the engagement in international markets.

Research was conducted on a sample of Polish large- and medium-sized companies, who utilize export activity as the main means of internationalization. Such companies have considerable experience operating on foreign markets and in investing their capital abroad. The level of internationalization of these companies could be measured by the share of total sales accounted for by foreign trade, and by the number of foreign manufacturing units. The results of research not described in this article show that other psychic distance stimuli (differences in culture, differences in economic systems, as well as differences in mentality and geographic distance) also affect the internationalization process of Polish companies.

Large and more internationalized companies seem to be more aware of the importance of political factors, as they are internationalizing their activity by foreign investment (which is connected with higher level of risk).

\section{Limitations and Future Research}

As with any study, the results would be interpreted in light of some limitations. The study was conducted within the context of one country, which may limit the generalizability of the results to some degree. Therefore, additional research should aim to test the framework in other countries as well. 
First, the results obtained did not allow identifying the impact of the level of internationalization of the company on the perceptions of managers about the significance on economic stimuli in market entry decisions. There are no explicit (univocal) results stating that the company's engagement abroad influences the perceptions of psychic distance (and economic factors). This disposed the author to conducting quantitative research on the bigger sample-200 companies. It will enable to generalize the results on the whole population.

Second, the use of managers responsible for foreign operations introduces a potential limitation in that it is possible that these managers do not constitute samples representative either of other managers or of the general population. In this study, the respondents were more likely to be more experienced in operating on foreign markets and aware of the conditions prevalent on the international environment.

In future, further research of a quantitative nature is needed, which will enable testing of the hypothesis and projection of the results onto the entire population. In general, further research in this field should provide a more comprehensive picture of the importance of psychic distance stimuli and allow for a preciser evaluation of its relationship with internationalization. Such quantitative research is in fact planned and will be conducted by means of face-to-face interviews. The main objective of this quantitative research will be the identification of the importance of cultural and systemic (economic and political) differences, as well as differences in mentality and geographic distance between Poland and the foreign markets into which Polish companies expand. Respondents will be asked to indicate, according to the Likert scale, the extent to which the host country of their business operations differs from their home country.

\section{Managerial Implications}

The research results show in which ways managerial perceptions of foreign countries (among other factors) systematically influence decisions' relating to companies' international activities. The perceptions of political and economic differences among or between countries may influence the attractiveness of foreign markets as perceived by managers. The research results may also be applied to a country's economic policy, with the aim of increasing the level of internationalization of companies. Such policy is focused on facilitating access for entrepreneurs to complex, high-quality information necessary for the planning, organization, and fulfillment of the requirements of exporting and foreign direct investment. Managers will therefore be supported by knowledge of and competencies in best-practice activity on international markets as well as the most successful strategies which may be realistically implemented on these international markets. They will also obtain information on the current state of business activity in different countries and on other continents.

\section{References}

Albaum, G., Strandskov, J., \& Duerr, E. (2002). International marketing and export management. Harlow, UK: Prentice Hall. Avloniti, A., \& Filippaios, F. (2014). Unbundling the differences between psychic and cultural distance: An empirical examination of the existing measures. International Business Review, 23(1), 660-674.

Beck, T., Clarke, G., Groff, A., Keefer, P., \& Walsh, P. (2001). New tools in comparative political economy: The database of political institutions. World Bank Economic Review, 15(1), 165-176.

Beckerman, W. (1956). Distance and the pattern of inter-European trade. The Review of Economics and Statistics, 38(1), 31-40.

Brewer, P. A. (2007). Operationalizing psychic distance: A revised approach. Journal of International Marketing, 15(1), 673-683.

Brouthers, K. D., \& Brouthers, L. E. (2001). Explaining the national cultural distance paradox. Journal of International Business Studies, 1(32), 177-189.

Carlson, S. (1974). International transmission of information and the business firm. The Annals of the American Academy of Political and Social Science, 412(1), 55-63. 
Child, J., Hong, S., \& Wong, C. (2003). Psychic distance and internationalization. International Studies of Management and Organization, 32(1), 36-56.

Child, J., Rodrigues, S. B., \& Frynas, J. B. (2009). Psychic distance, it's impact and coping modes interpretations of SME decision makers. Management International Review, 49(2), 199-224.

Dow, D. (2001). A note on psychological distance and export market selection. Journal of International Marketing, 8(1), 51-64.

Dow, D., \& Karunaratna, A. (2006). Developing a multidimensional instrument to measure psychic distance stimuli. Journal of International Business Studies, 37(5), 578-602.

Dow, D., \& Karunaratna, A. (2009). Factors influencing perceptions of psychic distance. AIB, San Diego, June 2009.

Dow, D., \& Larimo, J. (2009). Challenging the conceptualization and measurement of distance and international experience in entry mode choice research. Journal of International Marketing Research, 27(2), 74-98.

Evans, J., \& Mavondo, F. T. (2002). Psychic distance and organizational performance: An empirical examination of international retailing operations. Journal of International Business Studies, 33(3), 515-533.

Evans, J., Mavondo, F. T., \& Bridson, J. B. (2008). Psychic distance. Antecedents, retail strategy implications, and performance outcomes. Journal of International Marketing, 15(5), 364-374.

Freedom House. (2000). Freedom in the world. Retrieved from www.freedomhouse.com

Ghemawat, P. (2001). Distance still matters. The hard reality of global expansion. Harvard Business Review, 97(8), $137-147$.

Gleditsch, K. S. (2003). Modified polity P4 and P4D Data. Retrieved from http://weber.ucsd.edu

Goerzen, A., \& Beamish, P. (2003). Geographic scope and multinational enterprise performance. Strategic Management Journal, 24(130), 1289-1306.

Hakanson, L., \& Ambos, B. (2010). The antecedents of psychic distance. Journal of International Management, 16(3), $195-210$.

Harzing, A. W. (2004). The role of culture in entry modes studies: From negligence to myopia? In J. L. C. Cheng and M. A. Hitt (Eds.), Advances in International Management, 15, 75-127.

Henisz, W. J. (2000). The institutional environment of economic growth. Economics and Politics, 12(1), 1-31.

Holzmutter, H., \& Kasper, H. (1991). The decision-maker and export activity: A cross-national comparison of the foreign orientation of Austrian managers. Management International Review, 30(3), 217-230.

Johanson, J., \& Vahlne, J. E. (1977). The internationalisation process of a firm: A model of knowledge development and increasing foreign markets commitments. Journal of International Business Studies, 8(1), 23-32.

Johanson, J., \& Wiedersheim, P. F. (1975). The internationalisation of the firm: Four Swedish cases. Journal of Management Studies, 12(3), 305-322.

Jonsson, S., \& Lindbergh, J. (2010). The impact of institutional impediments and of information and knowledge exchange on SME's investment in international business relationships. International Business Review, 19(6), 548-561.

Kobrin, S. J. (1976). The environmental determinants of direct manufacturing investment: An ex-post empirical analysis. Journal of International Business Studies, 7(2), 29-42.

Kogut, B., \& Singh, H. (1988). The effect of national culture on the choice of entry mode. Journal of International Business Studies, 19(3), 411-432.

Miles, M. B., \& Huberman, A. M. (2000). Qualitative data analysis: An expanded sourcebook (2nd ed.). California: Sage.

Nordmann, E. R., \& Tolstoy, D. (2014). Does relationship psychic distance matter for the learning process of internationalizing SMSes? International Business Review, 23(1), 30-37.

Prime, N., Obadia, C., \& Vida, I. (2009). Psychic distance in exporter-importer relationships: A grounded theory approach. International Business Review, 18(2), 184-198.

Shoham, A., \& Albaum, G. S. (1995). Reducing the impact of barriers to exporting: A managerial perspective. Journal of International Marketing, 3(4), 85-105.

Sousa, C. M. P., \& Bradley, F. (2006). Cultural distance and psychic distance: Two pears in a pod? Journal of International Marketing, 14(1), 49-70.

Sousa, C. M. P., \& Bradley, F. (2005). Global markets: Does psychic distance matter? Journal of Strategic Marketing, 13(5), 43-59.

Sousa, C. M. P., \& Bradley, F. (2008). Cultural distance and psychic distance: Refirements in conceptualization and measurement. Journal of Marketing Management, 24(5), 307-320.

Sousa, C. M. P., \& Lages, L. F. (2011). The PD scale: A measure of psychic distance and its impact on international marketing strategy. International Marketing Review, 28, 201-222. 
Swift, J. S. (1999). Cultural closenest as a facet of cultural affinity. A contribution to the theory of psychic distance. International Marketing Review, 16(3), 182-201.

Tihanyi, L., Griffith, D., \& Russel, C. (2005). The effect of cultural distance on entry mode choice, international diversification, and MNE performance: A meta-analysis. Journal of International Business Studies, 36(3), 270-283.

Vahlne, J.-E., \& Wiedersheim-Paul, F. (1973). Economic distance: Model and empirical investigation. Uppsala: Department of Business Administration, University of Uppsala. 